\title{
Differentiation of infection structures of the powdery mildew fungus Uncinula necator and adhesion to the host cuticle
}

\author{
J. Rumbolz, H.-H. Kassemeyer, V. Steinmetz, H.B. Deising, K. Mendgen, D. \\ Mathys, S. Wirtz, and R. Guggenheim
}

\begin{abstract}
Development and adhesion of infection structures of the grapevine powdery mildew fungus. Uncinula necator (Schw) Burr., were investigated during the early stages of leaf colonization. Light microscopy showed that primary appressoria occurred $3.5 \mathrm{~h}$ post inoculation (p.i.) and that hyphae on the leaf surface, indicative of successful host colonization, appeared 14 h p.i. Low temperature scanning electron microscopy revealed deposits of extracellular material at the contact zone of fungal structures and plant cuticle, suggesting firm attachment of the pathogen. To investigate whether or not esterase or cutinase activity is involved in establishing the fungus on the host cuticle, histochemical assays and inhibitor studies were performed. Results indicated that esterase activity was associated with conidia and infection structures. A single fungal extracellular protein was identified as a cutinase by its ability to hydrolyze ${ }^{3} \mathrm{H}$-cutin. Probing Southern blots of genomic DNA of $U$. necalor, Magnaporthe grisea, and Fusaritum solani f.sp. pisi with the cutinase gene of $F$. solani f.sp. pisi suggested that the cutinase gene of $U$. necalor shares only limited sequence similarities with the cutinase genes of the other fungi investigated. Adhesion assays showed that the presence of esterase-cutinase inhibitors on the cuticle did not significantly affect adhesion. The role of the enzyme in fungal adhesion is discussed.
\end{abstract}

Key words: grapevine powdery mildew, Vitis vinifera, cutinase, extracellular matrix, cryofixation, low temperature scanning electron microscopy.

Résumé : Le développement et l'adhésion 'des structures infectieuses du champignon de l'oïdium de la vigne, Uncinula necator (Schw.) Burr., ont été étudiés pendant les premiers stades de la colonisation de la feuille. La microscopie optique a révélé un appressorium primaire $3.5 \mathrm{~h}$ après inoculation (p.i.) et un hyphe sur la feuille, indiquant le succès de la colonisation, $14 \mathrm{~h}$ p.i. En microscopie électronique à balayage des dépôts de matériel extracellulaire ont pu être observés sur la zone de contact entre les structures fongiques et la cuticule de la plante, suggérant un attachement ferme du pathogène. Pour rechercher si une activité cutinase ou estérase participait à l'établissement du champignon sur la cuticule de l'hôte, des études histochimiques et avec des inhibiteurs ont été conduites. Elles ont montré que l'activité estérase était associée avec les conidies er les structures infectieuses. Une seule protéine fongique extraceliulaire a été identifiée comme une cutinase par sa capacité à hydrolyser de la ${ }^{3} \mathrm{H}$-cutine. Des Southern blots d'ADN génomique d' $U$. necator: Magnaporthe grisea et Fusarium solani f.sp. pisi utilisant comme probe le gène de la cutinase de $F$. solani f.sp. pisi suggèrent que le gène de la cutinase d'U. necator ne partage que peu de zones de similarité de séquence avec les gènes de la cutinase des autres espèces étudiées. Des essais d'adhésion ont montré que la présence d'inhibiteurs d'estérase-cutinase sur la cuticule n’affectent pas significativement l'adhésion. Le rôle de l'enzyme dans l'adhésion du champignon est discuté.

Mots clés : oïdium de la vigne. Vitis vinifera. cutinase. matrice extracellulaire. cryofixation. microscopie électronique à balayage à basse témperature.

Received October 8. 1999

J. Rumbolz, ${ }^{1}$ H.-H. Kassemeyer, and V. Steinmetz. Staatliches Weinbauinstitut. Merzhauser Strasse 119. D-79100 Freiburg, Germans

H.B. Deising. Martin-Luther-Universität Haile-Wittenberg. Landwirtschaftliche Fakultät, Institut für Pflanzenzüchtung und Pflanzenschutz. Professur für Phytopathologie und Pflanzenschutz. Ludwig-Wucherer-Strasse 2. D-06099 Halle (Saale), Germany. K. Mendgen. Universität Konstanz, Fakultăt für Biologie. Lehrstuhl Phytopathologie. Universitätsstrasse 10, D-78434 Konstanz. German:.

D. Mathys. S. Wirtz, and R. Guggenheim. Universität Basel. Pharmazentrum, Labor für Rasterelektronenmikroskopie, Klingelbergstrasse 50. CH-4056 Basel, Switzerland

'Author to whom all correspondence should be sent at the following address: Universität Basel, Pharmazentrum. Labor für Rasterelektronenmikroskopie. Klingelbergstrasse 50, CH-4056 Basel, Switzerland (e-mail: Joachim.Rumbolz@unibas.ch). 


\section{Introduction}

Uncinula necator (Schw.) Burr. (anamorph Oidium tuckeri Berk.), the causal agent of grapevine powdery mildew, is an economically important pathogen in viticulture worldwide (Pearson and Goheen 1988). Epidemics of this obligate biotrophic fungus lead to both reduction of wine quality and yield loss. Despite intensive research over nearly 150 years (Bulit and Lafon 1978), knowledge of the biology of the fungus is still incomplete with respect to the early stages of its development within the infection process.

Like other powdery mildew fungi, $U$. necator gains access to the nutrients of its host by penetrating directly through the cuticle and epidermal cell wall with the subsequent formation of a haustorium. Indirect evidence suggests that penetration is achieved mainly by mechanical force (Heintz 1986; Heintz and Blaich 1990). In addition, powdery mildew fungi may also synthesize and secrete enzymes capable of degrading the cuticle and cell wall materials of the host plant (Pascholati et al. 1992; Frič and Wolf 1994; Suzuki et al. 1998).

Cutinases and cell wall degrading enzymes may play different roles and vary in importance in necrotrophic and biotrophic interactions (Mendgen and Deising 1993; Mendgen et al. 1996). Apart from their function in the penetration process of several plant pathogenic fungi (Shaykh et al. 1977; Podila et al. 1995), esterases and cutinases have been demonstrated to contribute significantly to the adhesion of urediospores of the broad bean rust fungus to the host cuticle (Deising et al. 1992).

Also, nonspecific esterases (Nicholson et al. 1988) and a cutinase (Pascholati et al. 1992) are components of the liquid exudate that is released by the conidia of Erysiphe graminis upon contact with the host cuticle and artificial substrata (Kunoh et al. 1988; Carver et al. 1999). Scanning electron micrographs have documented that this liquid flows off the conidia to spread on the substratum. thereby binding the propagules to the underlying surface (Kunoh et al. 1988). These observations have recently been confirmed by Roberts and Mims (1998), using transmission electron microscopy. It has also been proposed that, in this powdery mildew fungus, the secretion of the cutinase-containing exudate onto the host surface is important for cuticle erosion (Kunoh et al. 1990), host recognition, and the induction of infectionstructure differentiation (Nicholson et al. 1993: Francis et al. 1996). Recent studies with light and low temperature scanning electron microscopy (LTSEM) have shown that the release of the exudate occurs in a time- and substratumdependent manner (Carver et al. 1999).

Such events preceding penetration of a plant cell have been summarized as "preparation of the infection court" (Nicholson and Kunoh 1995), leading to firm adhesion of the fungal spore. which could otherwise be removed by wind and rain. In addition to conidial exudates, Carver et al. (1995a. 1995b) demonstrated that extracellular material is associated with primary and appressorial germ tubes of E. graminis, presumably acting as an adhesive.

Spore adhesion appears to be crucial for the establishment of many plant pathogens (Nicholson 1996; Epstein and Nicholson 1997; Dean 1997), including powdery mildew fungi. Studies of several powdery mildew species have dem- onstrated that subsequent fungal development was inhibited after inoculated leaves of host plants were impacted by water droplets (Sivapalan 1993). For U. necator, a suppressive effect of water applications on sporulation has been reported (Chellemi and Marois 1991). However, to date, there has been no investigation of this important pathogen with regard to the developmental stages most susceptible to removal of conidia and infection structures by water. Therefore, we analyzed the initial stages in the infection of grapevine by $U$. necator, using LTSEM and light microscopy in combination with biochemical methods. The purpose was to achieve a better understanding of the mechanisms of adhesion and their relation to the developmental progress of the fungus.

\section{Materials and methods}

\section{Fungal and plant material}

Uncinula necator Schw. (Burr.) (anamorph Oidium tuckeri Berk.) was maintained on cuttings of grapevine (Vitis vinifera $\mathrm{L}$. $c v$. Müller-Thurgau). Plants were grown under greenhouse conditions $\left(18-26^{\circ} \mathrm{C}\right.$, natural photoperiod). Leaf material to be used in germination and adhesion experiments was taken from uninfected greenhouse plants from April to October. To propagate the fungus, conidia from 10- to 14-day-old colonies were brushed onto leaves of uninfected plants. For histochemical assays, inoculated plants were maintained in growth chambers $\left(24^{\circ} \mathrm{C}\right.$; light intensity $7 \mathrm{~W}$. $\mathrm{m}^{-2} \cdot \mathrm{s}^{-1}: 16 \mathrm{~h}$ light $(\mathrm{L}): 8 \mathrm{~h}$ dark (D)). Developing conidia were "harvested 10-14 days post inoculation (p.i.), by brushing off spores from sporulating colonies.

For infection structure differentiation and adhesion experiments, $U$. necator was propagated under controlled conditions $\left(24^{\circ} \mathrm{C} ; 50 \%\right.$ RH: light intensity $\left.7 \mathrm{~W} \cdot \mathrm{m}^{-2} \cdot \mathrm{s}^{-1} ; 16 \mathrm{~h} \mathrm{~L}: 8 \mathrm{~h} \mathrm{D}\right)$. Conidia were taken between 7 and 10 days p.i.

Fusarium solani f.sp. pisi (teleomorph Nectria haematococca) isolate MP VI (Stahl and Schäfer 1992) was obtained from W Schäfer (University of Hamburg, Germany) and maintained on 2\% agar supplemented with $5 \%$ biomalt. Magnaporthe grisea (teleomorph Pyricularia grisea) wild type 70-15 was obtained from R.A. Dean. Clemson University. U.S.A., and cultured on oatmeal agar (Lee and Dean 1993).

\section{Infection-structure differentiation}

Leaves were surface-sterilized by wiping the surface briefly with a paper tissue soaked with $70 \%$ ethanol and washed twice in sterile water before use. Leaf disks (diameter $13 \mathrm{~mm}$ ) excised with a cork borer were placed on water agar $(1 \%)$ in Petri dishes with the abaxial surface facing the agar (10 leaf disks per Petri dish; 3 dishes per experiment). Disks were inoculated by brushing conidia from 10- to 14-day-old colonies of $U$. necator onto the disks (see above) and incubated for various periods of time ( $1-48 \mathrm{~h} \mathrm{p.i.)}$ at $24^{\circ} \mathrm{C}$ and $100 \% \mathrm{RH}$. Developmental stages were defined (SI. germ tube: S2, germ tube-initiated primary appressorium: S3. primary appressorium: S4. primary hypha; S5. secondary hypha) and leaf disks. taken randomly from one of three dishes after incubation, were counted for the respective stages. For each period of time. the portion of single developmental stages was assessed by checking all conidia on one disk. The average number of spores counted on one disk was 105 (standard deviation $(S D)=25$ ). Data assessment was carried out continuously at 20 - to 40 -min intervals until $9.5 \mathrm{~h}$ p.i. Intervals were then prolonged up to $1.5 \mathrm{~h}$. The experiment was repeated 3 times.

Developmental stages of $U$. necator on leaf disks were stained for $15-30 \mathrm{~min}$, using a $0.1 \%$ solution of the fluorochrome Blankophor BUP New (Bayer AG. Monheim, Germany) in $50 \mathrm{mM}$ Tris-HCl ( $\mathrm{pH} \mathrm{8.0).} \mathrm{After} \mathrm{the} \mathrm{removal} \mathrm{of} \mathrm{excess} \mathrm{dye} \mathrm{by} \mathrm{dipping} \mathrm{the}$ 
leaf disks in distilled water, stained fungal structures were observed and photographed under a Zeiss Axiophot light microscope equipped with an epifluorescence device (excitation at $365 \mathrm{~nm}$; low pass at $397 \mathrm{~nm}$ ).

\section{Adhesion assays}

To assess the time course of conidial adhesion, leaf disks were prepared and incubated for various periods of time (from $10 \mathrm{~min}$ to $35 \mathrm{~h} \mathrm{p.i.)} \mathrm{as} \mathrm{described} \mathrm{above.} \mathrm{Before} \mathrm{the} \mathrm{end} \mathrm{of} \mathrm{each} \mathrm{incubation}$ period. 3-6 leaf disks were taken randomly from Petri dishes and counted for conidia under the light microscope (Plan-Neofluar 10x). Disks were placed on an agar plate attached to an inclined ramp (angle $28^{\circ}$ ) to ensure that water would run off. Then, disks were washed with 25 droplets of distilled water delivered from a height of $9.5 \mathrm{~cm}$. Conidia remaining on leaf disks were counted, and adhesion was expressed as the percentage of conidia remaining on the leaf surface. The experiment was repeated 12 times independently.

To assess the effect of the cutinase inhibitor BIC (butylisocvanate; Aldrich Chemicals, Deisenhofen, Germany) on adhesion, adaxial surfaces of leaf disks of $V$. vinifera (see germination experiments) were covered with 0.1 or $1 \mathrm{mM} \mathrm{BIC}$ in $50 \mathrm{mM}$ Tris-HC ( $\mathrm{pH} 7.2$ ) containing $0.01 \%$ Tween 20 . Controls were treated with $50 \mathrm{mM}$ Tris- $\mathrm{HCl}(\mathrm{pH} 7.2)$ containing $0.01 \%$ Tween 20 . The solutions were allowed to dry and the disks were then inoculated with conidia and incubated for $10 \mathrm{~h}$ at $17^{\circ} \mathrm{C}$ and $100 \% \mathrm{RH}$. These conditions correspond to an incubation period of $4-5 \mathrm{~h}$ at $24^{\circ} \mathrm{C}$. During this period, conidia germinated and started to form appressoria. Incubation at $17^{\circ} \mathrm{C}$ was then continued, to give a total incubation period of up to $36 \mathrm{~h}$. After incubation, the adhesion of conidia was determined as described above.

For statistical analyses, a nonlinear regression was carried out using SAS (SAS Institute Inc., Cary, N.C., U.S.A.). The logistic function

$$
f(x)=\left(a_{1} /\left(1+a_{2} \times \exp \left(-a_{3} \times x\right)\right)\right)+a_{4}
$$

was fitted to values obtained from the adhesion assays (see Fig. 3 ). The logistic function

$$
\text { [2] } \quad f(x)=a_{1} /\left(1+a_{2} \times \exp \left(-a_{3} \times x-a_{4}\right)\right)
$$

w'as fitted to accumulated values of each developmental stage of the germination assay (see Fig. 2).

\section{Cryofixation and LTSEM}

Untreated (control) or BIC-treated leaf disks $(0.1$ or $1 \mathrm{mM} \mathrm{BIC}$ ) and berries of $V$. vinifera were inoculated with conidia as described. In addition. leaves of Hordeum vulgare L. (cv. Hanna) with cuticles freed of epicuticular waxes (Carver and Thomas 1990). glass slides. and a hydrophobic PVDF (polyvinylidene difluoride) blotting membrane (Macherey and Nagel. Düren, Germany) were inoculated. Germinated spores and appressoria were examined with LTSEM. according to Guggenheim et al. (1991), after $10 \mathrm{~h}$ at $17^{\circ} \mathrm{C}$. To check whether penetration had occurred, gelatin $(20 \% \mathrm{w} / \mathrm{r})$ was poured on the disks and stripped off, together with fungal infection structures, after solidification. Subsequently, $0.8-$ to $1-\mathrm{cm}^{2}$ pieces were cut out from the leaf disks, mounted on a Balzers specimen table using low-temperature mounting medium, and rapidly frozen by plunging into liquid nitrogen. After cryofixation. samples were transferred under nitrogen gas to a Balzers cryopreparation unit SCU 020 attached to a JEOL JSM 6400 scanning electron microscope (SEM). lce crystals on the surface were allowed to sublime from the specimens by raising the temperature to $-80^{\circ} \mathrm{C}$ for $10 \mathrm{~min}$. Samples were sputter-coated with gold (to $20 \mathrm{~nm}$ ' in an argon gas atmosphere (Müller et al. 1991). In freezefractunno experiments. samples were fractured at $-120^{\circ} \mathrm{C}$ with a precooled krife prior to sputter-coating. Coated specimens were transferred online into the SEM under high-vacuum conditions. The samples were observed and photographed at a stage temperature of $-165^{\circ} \mathrm{C}$, using an accelerating voltage between 5 and $25 \mathrm{kV}$

\section{Histochemical assay for localization of fungal-esterase activity}

Esterase activity associated with the spores was analyzed using indoxyl acetate (Sigma Chemicals, Deisenhofen, Germany) as the chromogenic substrate (Barnett and Seligman 1951). Gelatin containing indoxyl acetate (17.5\% gelatin (in $20 \mathrm{mM}$ Tris- $\mathrm{HCl}(\mathrm{pH}$ 8.0)) containing $0.99 \mathrm{M} \mathrm{NaCl}, 44.6 \mathrm{mM} \mathrm{CaCl}$, and $3.4 \mathrm{mM}$ indoxyl acetate) was inoculated with conidia of $U$. necator and incubated for $1-4 \mathrm{~h}$ at $24^{\circ} \mathrm{C}$ and a light intensity of $7 \mathrm{~W} \cdot \mathrm{m}^{-2} \cdot \mathrm{s}^{-1}$. Indigo blue crystals resulted from hydrolysis of the substrate at the site of enzyme action. Spores were examined and photographed with a Zeiss Axiophot light microscope (Plan-Neofluar 63x). Autoclaved conidia $\left(30 \mathrm{~min}, 120^{\circ} \mathrm{C}, 1.1\right.$ bar $(1 \mathrm{bar}=100 \mathrm{kPa})$ ) on gelatin containing indoxyl acetate served as the control. On inoculated glass slides, appressoria formed after $3.5 \mathrm{~h}$ of incubation. Infection structures were stained by misting with a $50 \mathrm{mM}$ Tris buffer (pH 8.0) containing $4 \mathrm{mM}$ indoxyl acetate, followed by incubation for a further $16 \mathrm{~h}$ at $24^{\circ} \mathrm{C}$. Controls were heat-treated at $75^{\circ} \mathrm{C}$ for 30 min prior to spray application of the substrate.

\section{Preparation of washing solutions from spores and appressoria}

Spore washing solutions were obtained from uninfected leaves that had been inoculated with conidia from 120 heavily infected grapevine leaves and incubated for $4 \mathrm{~h}$ at $24^{\circ} \mathrm{C}$ and $50 \% \mathrm{RH}$ in Petri dishes. Conidia germinated and started to form appressoria by $4 \mathrm{~h}$ p.i. These structures were washed off the leaves with $50 \mathrm{mM}$ Tris- $\mathrm{HCl}(\mathrm{pH} 7.2$ ) containing $0.01 \%$ Tween 20 , and washed five times by stirring on a Vortex with subsequent centrifugation ( $5 \mathrm{~min}$ at $15000 \times g)$. After filtration $(100 \mathrm{~N}$, pore size $0.8 \mu \mathrm{m}$; Sartorius. Edgewood, U.S.A.), the crude washing solution was concentrated 100 -fold by ultrafiltration (Centriprep/Centricon 10; Amicon/Millipore, Bedford, Mass.). Controls included washing solutions from the same number of leaves without inoculum.

\section{Esterase assay}

Extracellular esterase activity from spores and appressoria was determined by measuring the hydrolysis of $p$-nitrophenyl butyrate (Sigma chemicals, Deisenhofen, Germany) at $400 \mathrm{~nm}$, as described previously (Huggins and Lapides 1947). Reaction mixtures consisted of $0.6 \mathrm{~mL}$ of $0.1 \mathrm{M}$ Tris- $\mathrm{HCl}$ buffer ( $\mathrm{pH} 8.0$ ), $0.2 \mathrm{~mL}$ of enzyme preparation, and $0.2 \mathrm{~mL}$ of $37.5 \mathrm{mM} p$-nitrophenyl butyrate in $0.1 \mathrm{M}$ Tris- $\mathrm{HCl}(\mathrm{pH} 8.0)$. Inhibition of enzyme activity was assayed using serine esterase inhibitors: either diisopropylfluorophosphate (DIPF, 10 or $100 \mu \mathrm{M}$; Sigma Chemicals, St. Louis, Mo.: Kolattukudy et al. 1981) or BlC (10 or $100 \mu \mathrm{M}$; Köller et al. 1982). Assays were run at $25^{\circ} \mathrm{C}$.

\section{Nondenaturing PAGE and enzyme elution from gels}

Extracellular fungal proteins were separated by nondenaturing PAGE using the buffer system described by Laemmli (1970) but without SDS. The running gel contained $10 \%$ polyacrylamide, while the stacking gels contained $5 \%$. Gels were run at $4^{\circ} \mathrm{C}$ and a constant current of $100 \mathrm{~V}$ for $13 \mathrm{~h}$. After washing in $100 \mathrm{mM}$ Tris$\mathrm{HCl}(\mathrm{pH} 8.0)$ for $2 \times 20 \mathrm{~min}$, protein bands with esterase activity were detected by incubating the gels in $100 \mathrm{mM}$ Tris buffer (pH 8.0) containing $4 \mathrm{mM}$ indoxyl acetate (Deising et al. 1992).

To test for cutinolytic activity, esterase bands were excised from acrylamide gels, frozen, and ground to powder in liquid nitrogen. Protein was eluted by stirring with $\mathrm{H}_{2} \mathrm{O}$ at $4^{\circ} \mathrm{C}$ for $2 \mathrm{~h}$ and centrifuging ( $10 \mathrm{~min}$ at $15000 \times \mathrm{g}$ at $4^{\circ} \mathrm{C}$ ), with subsequent freezedrying of the supernatant overnight. To localize esterases, reference 
Figs. 1 and 2. Infection-structure differentiation of $U$. necator. Fig. 1. Fluorescence micrographs showing early development of $U$. necaror. Time indicates first occurrence of the respective stage after incubation at $24^{\circ} \mathrm{C}$ and $100 \%$ RH. Fig. 2. Time course of infectionstructure differentiation on leaf disks of $V$. vinifera $\mathrm{cv}$. Müller-Thurgau at $24^{\circ} \mathrm{C}$. Data points represent accumulated values of single developmental stages (Fig. 1, S1-S5) from four independent experiments. Curves were obtained by fitting a logistic function $\left(f(x)=a_{1} /\right.$ $\left(1+a_{2} \times \exp \left(-a_{3} \times x-a_{4}\right)\right)$ to the plotted values: $S 1$ (emerging germ tube): $a_{1}=76.50$; uncertainties (confidence interval of $\left.90 \%\right)$ : $\Delta a_{1}=1.69 ; \mathrm{S} 2$ (germ tube - initiated primary appressorium) $a_{1}=74.45 ; \Delta a_{1}=1.84 ; \mathrm{S} 3$ (mature primary appressorium): $a_{1}=70.32:$ $\Delta a_{1}=5.98 ; S 4$ (primary hypha): $a_{1}=21.75 ; \Delta a_{1}=6.41 ;$ and S5 (secondary hypha): $a_{1}=17.98 ; \Delta a_{1}=4.31$.
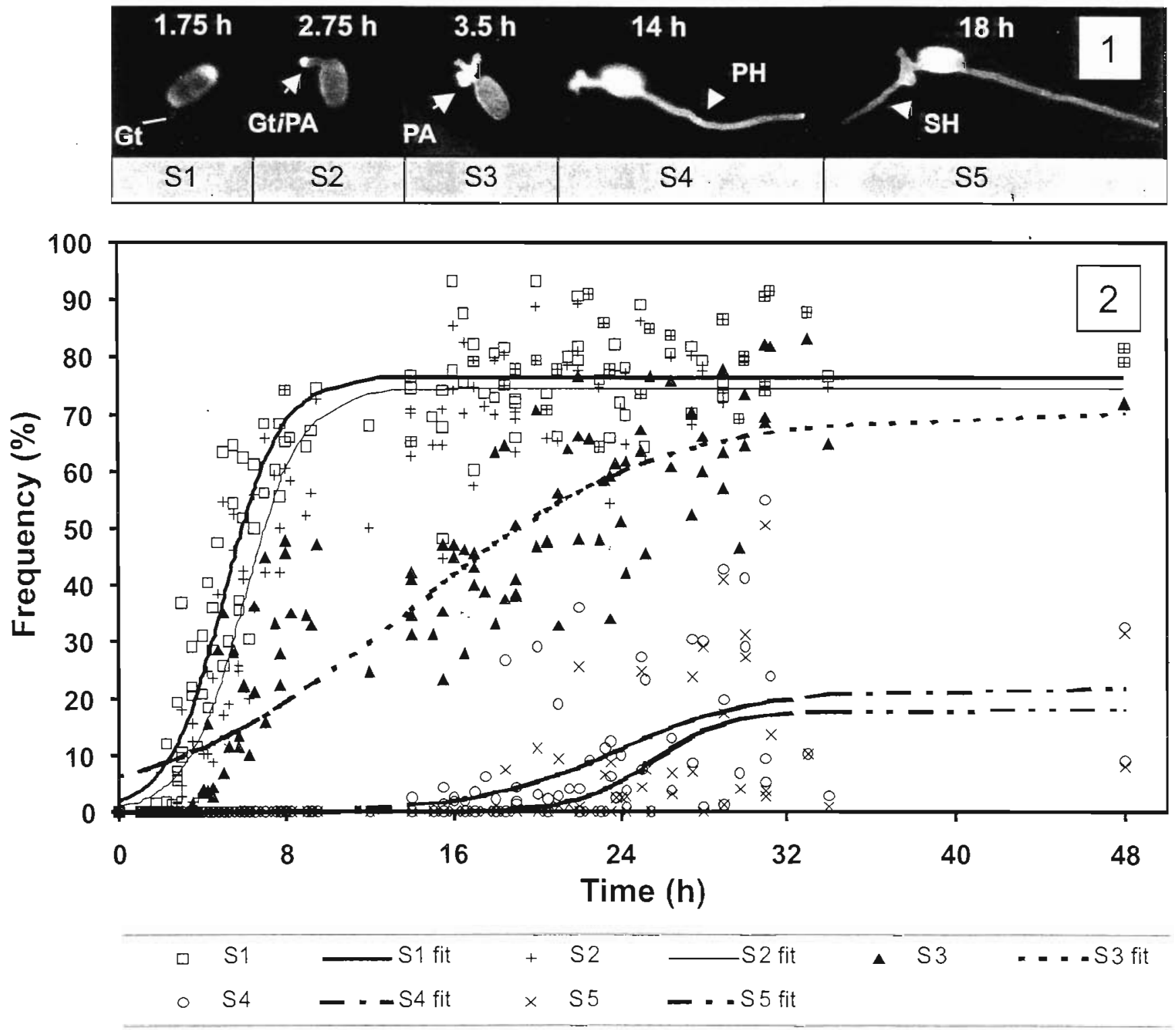

lanes of the gels were stained with indoxyl acetate as described abov'e.

\section{Cutinase assay}

Lyophilized protein eluted from one esterase-positive band of $4-$ 6 polvacrylamide gels ( 7 lanes each) was dissolved in $300 \mu \mathrm{L}$ of $50 \mathrm{mM}$ Tris- $\mathrm{HCl}$ ( $\mathrm{pH} 8.9$ : reaction buffer) and centrifuged (10 min at $10000 \times g$ ) to remove gel fragments. Cutinase assays were performed as described by Bonnen and Hammerschmidt (1989), with minor modifications. Tritiated cucumber cutin $(4.5 \mathrm{mg}$; generous gift of R.L. Nicholson, Purdue University, U.S.A.) with a specific activity of $10^{6} \mathrm{dpm} / \mathrm{mg}(1 \mathrm{dpm}=0.0167 \mathrm{~Bq})$ was washed four times with $1 \mathrm{~mL}$ of reaction buffer at $32^{\circ} \mathrm{C}$ for 20 min each wash.
After final centrifugation. the cutin was resuspended in $0.72 \mathrm{~mL}$ of buffer. Reaction mixtures consisted of $100 \mu \mathrm{L}$ of ${ }^{3} \mathrm{H}$-cutin suspension. $50 \mu \mathrm{L}$ of enzyme preparation. $325 \mu \mathrm{L}$ of reaction buffer. and $25 \mu \mathrm{L}$ of $2 \%(\mathrm{w} / \mathrm{v})$ Thimerosal (Sigma Chemicals. St. Louis. Mo.). Inhibition assays contained the cutinase inhibitor DIPF $(10 \mu \mathrm{M})$. In controls, buffer was substituted for the enzyme preparation. Reactions were terminated after $40 \mathrm{~h}$ of incubation at $32^{\circ} \mathrm{C}$ by adding $50 \mu \mathrm{L}$ of $6 \mathrm{M} \mathrm{HCl}$. Reaction mixtures were centrifuged (10 min at $15000 \times g$ at room temperature) and the supernatant was partitioned three times with $1 \mathrm{~mL}$ of diethyl ether. Ether phases were collected and dried under nitrogen. Scintillation cocktail ( $4 \mathrm{~mL}$; Ultima Gold. Packard, Groningen. The Netherlands) was added and radioactivity was counted after $1-2 h$. The enzy- 
matic release of cutin monomers was calculated by subtracting the radioactivity measured in controls from the activity recorded in enzrme assays. Protein concentration was determined in $50-\mu \mathrm{L}$ samples of all protein preparations extracted from the polyacryIamide gels. using a commercially available protein assay (BioRad. München. Germany) (Bradford 1976). Bovine serum albumin served as the standard.

\section{Southern-blot analysis}

Total DNA from U. necator, $F$. solani f.sp. pisi, and $M$. grisea was isolated according to Möller et al. (1992); digested with the restriction enzymes BamHI, EcoRI, and HindIII; fractionated on $0.8 \%$ agarose-TAE ( $40 \mathrm{mM}$ Tris-acetate $-2 \mathrm{mM}$ EDTA) gels: and blotted onto nylon membrane (Boehringer Mannheim, Mannheim, Germany) by alkaline capillary transfer (Sambrook et al. 1989). Hybridization $\left(68^{\circ} \mathrm{C}, 18 \mathrm{~h}\right)$ and detection with the chemoluminescent agent CSPD (disodium 3-(4-methoxyspiro\{1,2-dioxetane3.2'-(5'-chloro)tricyclo[3.3.1.13,7]decan $\}$-4-yl) phenyl phosphate; Boehringer Mannheim) was carried out according to the DIG (digoxigenin) System User's Guide (Boehringer Mannheim 1995). A DIG-labeled 500-bp insert of a cutinase gene of Nectria haematococca isolate T8 (Stahl and Schäfer 1992) was synthesized by PCR, using the M 13 universal and reverse primers, plasmid $p \Delta C u t 22$ (generous gift of W. Schäfer, Universität Hamburg, Germany) as the template. and Taq polymerase ( $5 \mathrm{U} / \mathrm{ML}$ ), according to manufacturer's instructions (Dig System User's Guide. Boehringer Mannheim).

\section{Results}

\section{Germination of conidia and mildew infection structure} differentiation and adhesion to the host surface

Conidial germination and $U$. necator infection structure development was followed microscopically on leaf disks of $\because$ inifera. At the optimum temperature $\left(24^{\circ} \mathrm{C}\right.$; Delp 1954) germination started $1.75 \mathrm{~h}$ p.i. First, a germ tube emerged from the apical end of the conidium (Fig. 1). The germ tube swelled at its distal end (2.75 h p.i.) and subsequently matured to form a lobed primary appressorium (3.5 h p.i.). The nierall percentage of germinated conidia reached values of $70-80 \%$ by 10 h p.i. (Fig. 2, S1). For the first developmental stages ( $1-S 3)$. that is, from germination to the formation of primary appressoria, a significant increase in frequency was found between 2 and $8 \mathrm{~h}$ p.i. Data points show that the number of conidia with a differentiated primary appressorium (S3) increased dramatically until $8 \mathrm{~h}$ p.i.. then continued to increase more slowly to values of approximately $70 \%$ after $30 \mathrm{~h}$. and remained constant thereafter.

Primary hyphae, indicative of successful colonization of the leaf tissue by the powdery mildew fungus, first appeared if $\mathrm{h} \mathrm{p.i.} \mathrm{Within} \mathrm{the} \mathrm{time} \mathrm{frame} \mathrm{of} \mathrm{the} \mathrm{experiment}(48 \mathrm{~h})$. slightly more than $20 \%$ of the conidia produced primary hyphae. The following stage, that is. formation of secondary hyphae. was reached by less than $20 \%$ of the conidia on average. Secondary hyphae appeared $18 \mathrm{~h}$ p.i.

In parallel. adhesion assays showed that conidia could be washed off easily from the leaf surface before the onset of germination (Fig. 3). Between 3 and $8 \mathrm{~h}$ p.i., the percentage of adhering germlings increased from a base level of $15 \%$ $(0-3$ h p.i. $)$ to a level of about $70 \%$ after 8 h. Longer incubalion times did not result in higher rates of adhesion (Fig. 3. insert).
Fig. 3. Adhesion of conidia of $U$. necator on leaf disks of $V$ vinifera $\mathrm{cv}$. Müller-Thurgau from 0 to $10 \mathrm{~h}$ p.i.; inset, from 0 to $35 \mathrm{~h}$ p.i. The curve was obtained by fitting a logistic function $\left(f(x)=\left(a_{1} /\left(1+a_{2} \times \exp \left(-a_{3} \times x\right)\right)\right)+a_{4}\right)$ to values of 13 independent experiments: $a=a_{1}+a_{4}=68.81$ : uncertainties (confidence interval of 90\%): $\Delta a_{1+4}=5.74$. Symbols as in Fig. 2 .

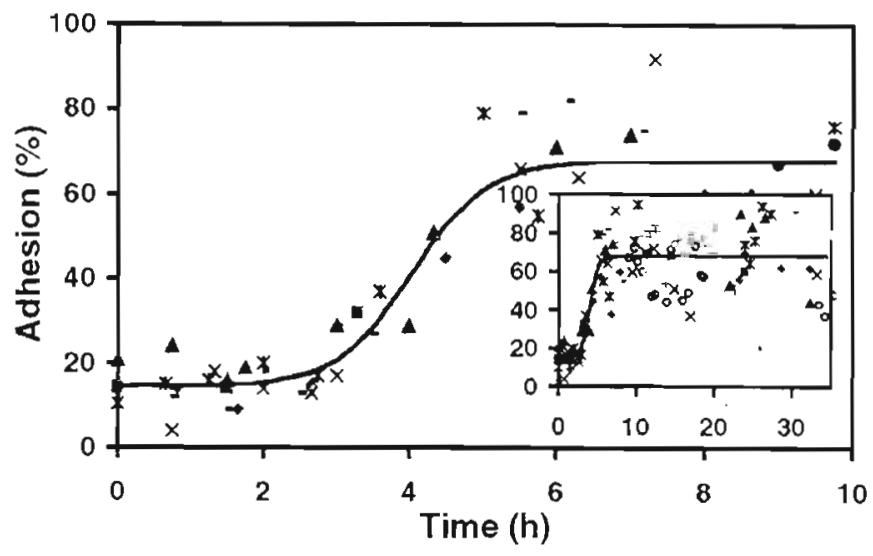

\section{LTSEM of early infection structures}

\section{Attachment}

LTSEM studies were carried out to examine the development of infection structures of $U$. necator on the host cuticle up to the formation of mature appressoria.

The surface of conidia attached to a conidiophore appeared unevenly structured except for the smooth ends (Fig. 4). Occasionally, a reticulate structure was observed on the conidial surface upon contact with the plant tissue (Fig. 5). The spore appeared to be covered by an additional layer that must have been penetrated by the emerging germ tube.

Primary appressoria were always firmly attached to the surface of untreated leaf disks and berries of $V$. vinifera (Figs. 6 and 7). At the contact zone, deposits of extracellular material or cuticular dissolutions were visible (Figs. 6 and 7). To examine the underlying cuticle for imprints of infection structures, germinated spores had to be displaced. We tried previously described methods to strip off fungal structures, viz., gelatin (Staub et al. 1974) or adhesive tape (Deising et al. 1992). Neither method gave satisfactory results, because infection structures were removed completely. In contrast, fracturing specimens inside the cryopreparation unit produced displaced or ruptured infection structures. Fractures of adhering fungal structures occurred mainly at the neck of appressoria, leaving behind undamaged appressoria (Fig. 8). Traces of the corresponding spores were also visible on the host surface. Fracturing the leaf disk underneath a germ tube revealed shreds of adhesive material on the host surface that corresponded to what was found on the surface of the appressorial neck (Fig. 9).

\section{Histochemical localization of esterase activity}

LTSE micrographs of the contact zone between fungal structures and the plant surface that showed signs of cuticle erosion (Figs. 4-9) encouraged us to assay for esterase activity in the early stages of development. 
Figs. 4-9. LTSE micrographs of germination stages and attachment of $U$. necator: Fig 4. Conidium (C) attached to the conidiophore $(\mathrm{Cp})$. Fig. 5. Germinating conidium (C). The reticulate surface appears as an additional layer perforated by the emerging germ tube (Gt). Fig. 6. Primary appressorium (PA) on the leaf cuticle $(\mathrm{Cu})$ of $V$. vinifera (ECM, extracellular material). Fig. 7. Primary appressorium (PA) on the berry cuticle $(\mathrm{Cu})$ of V. vinifera (ECM, extracellular material). Fig. 8. Remnants of germinated conidia (A*, imprint of primary appressorium; $C^{*}$, imprint of conidium: PA, primary appresorium) of $U$. necator on a freeze-fractured leaf disk of V. vinifera. Conidia were displaced completely or broken off at the appressorial neck (An). Fig. 9. Germinated conidium (C) of U. necator with primary appressorium (PA). The tightly adhering appressorium was partly removed from the host surface, leaving behind shreds of extracellular material (arrows).

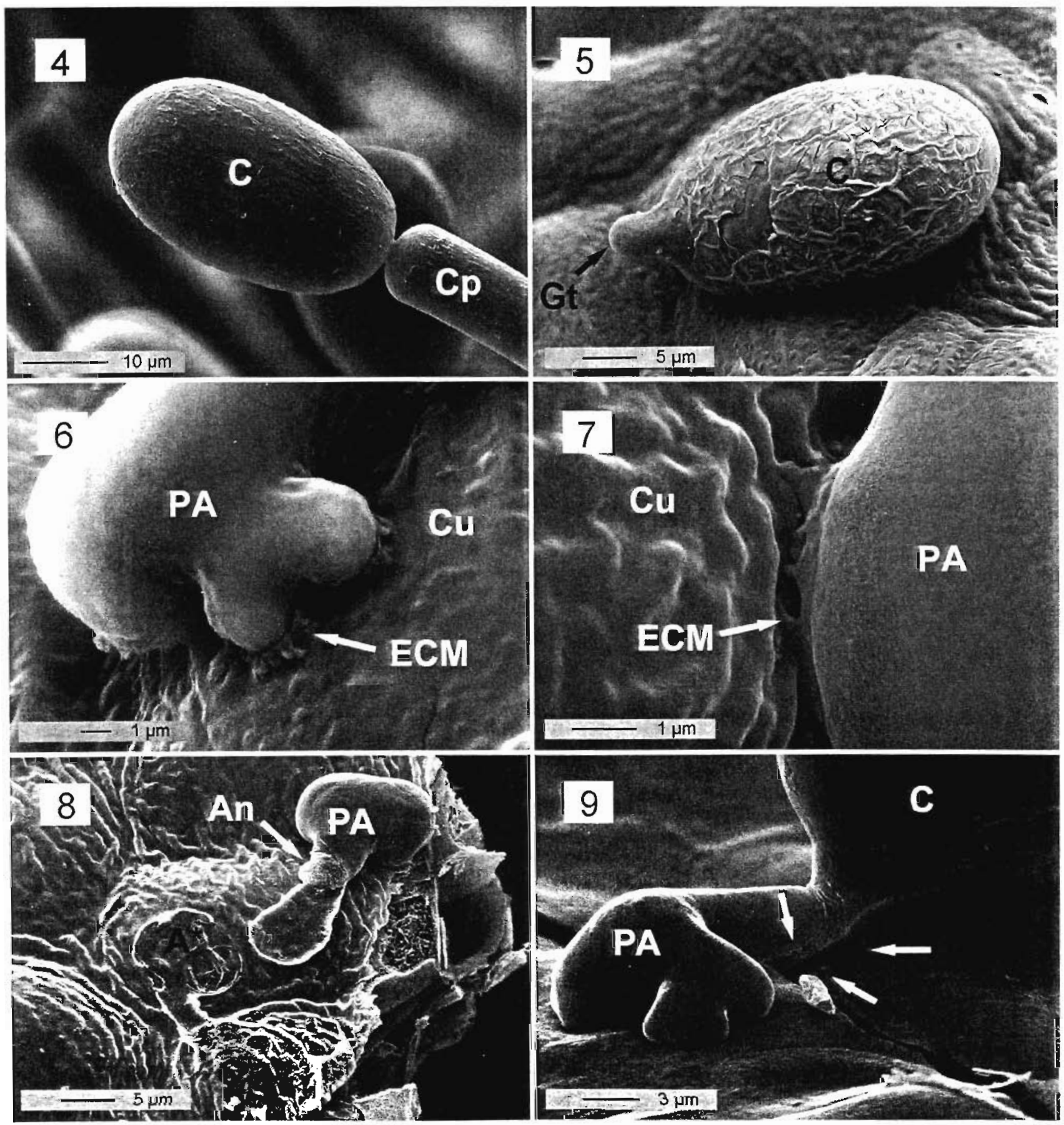

Conidia of $U$. necator on gelatin containing the esterase substrate indoxyl acetate showed esterase activity. Blue indigo crystals, resulting from substrate hydrolysis, developed within $1-2$ h after inoculation (Fig. 10). Longer incubation periods led to more intense staining of the conidia. In this case, indigo crystals also developed around spores and a gradient towards spores was visible at lower magnification, especially around aggregates of several spores (data not shown). Crystals were not found in controls with autoclaved spores (Fig. 11). Glass slides were also inoculated with 
conidia, because appressoria do not differentiate on gelatin. Esterase activity. as indicated by the formation of indigo crystals, was associated with germinated conidia and primary appressoria (Fig. 12). Crystals also developed at a distance of some micrometres around fungal structures. In contrast, when inoculated glass slides were heated before staining, indigo crystals did not form (Fig, 13).

The application of small amounts of spore washing solutions containing esterase activity (see below) to the gelatin surface with a microsyringe also led to the formation of indigo crystals radially around the deposition site (data not shown). In contrast, indigo crystals never formed when heattreated samples were applied to the substratum.

\section{Esterase and cutinase activity in washing solutions of grapevine leaves inoculated with conidia of $U$. necator}

Washing solutions of grapevine leaves inoculated with conidia of the powdery mildew fungus $U$. necator showed esterase activity, as measured with $p$-nitrophenyl butyrate. At a concentration of $100 \mu \mathrm{M}$, the serine esterase inhibitors DIPF and BIC inhibited esterase activity by 52 and $77 \%$, respectively (Table 1); at a lower concentration $(10 \mu \mathrm{M}$ ), no significant inhibition was found. Esterase activity was not detected in washing solutions obtained from uninoculated control leaves. Analysis by nondenaturing PAGE and the nonspecific esterase substrate indoxyl acetate suggested that only one esterase form is associated with mildew infection structures on the grapevine cuticle (Fig. 14). To test whether the esterase exhibits cutinase activity, the indoxyl acetate stained band was excised and the protein present at this position was eluted from the polyacrylamide gels. The eluted enzyme hydrolyzed ${ }^{3} \mathrm{H}$-cutin, indicating that the esterase secreted by mildew infection structures is a cutinase (Table 1). Comparable with esterase activity, cutinase activity was inhibited in the presence of $10 \mu \mathrm{M}$ DIPF by $54 \%$ (Table 1 ).

\section{Homology among cutinase genes}

To provide estimates of the homology between the cutinase genes of two necrotrophic pathogens and an obligate biotroph. comparative genomic Southern blot analyses were performed under high stringency conditions with DNA from $U$. necator: $F$. solani f.sp. pisi, and $M$. grisea, using the cutinase gene from $F$. solani f.sp. pisi as a hybridization probe. The strongest hybridization signals for the DIGlabeled 500-bp probe were obtained with genomic DNA from $F$. solani f.sp. pisi (Fig. 15). Two fragments of $>10 \mathrm{~kb}$ (Fig. 15, lanes 5 and 7) and one fragment of approximately $7 \mathrm{~kb}$ (Fig. 15. lane 6) were visible. Extended exposure times revealed faint bands at 6 and $9 \mathrm{~kb}$ (Fig. 15. lane 5) and $2.3 \mathrm{~kb}$ (Fig. 15. lane 6). With genomic DNA of $M$. grisea. weak hybridization signals were also seen at $3.5 \mathrm{~kb}$ (Fig. 15 , lane 8 ) and $4 \mathrm{~kb}$ (Fig. 15. lane 9). Even at extended exposure times. no detectable hybridization of the $F$. solani f.sp. pisi cutinase probe occurred with DNA from U. necator (Fig. 15, Janes 2-4).

\section{LTSEM of early infection structures}

\section{Extracellular material}

Comparisons of the differentiation of primary appressoria on host (Figs. 6-9, 16, and 17) and non-host (Figs. 18 and
Figs. 10-13. Light micrographs showing the localization of esterase on conidia and infection structures of $U$. necator. Indigo crystals (arrows) indicate esterase activity. Figs. 10 and 11. Conidia after incubation $\left(24^{\circ} \mathrm{C}, 3 \mathrm{~h}\right)$ on a gelatin surface containing indoxyl acetate. Fig. 10. Untreated spores. Fig. 11. Autoclaved spore. Figs. 12 and 13. Conidia after incubation $\left(24^{\circ} \mathrm{C}\right.$, $5 \mathrm{~h}$ ) on glass slides. Developing infection structures were misted with $50 \mathrm{mM}$ Tris buffer ( $\mathrm{pH}$ 7.2) containing indoxyl acetate and incubated for a further $16 \mathrm{~h}$ at $24^{\circ} \mathrm{C}$. Fig. 12. Untreated spore. Fig. 13. Heat-treated spores. Scale bar $=30 \mu \mathrm{m}$.

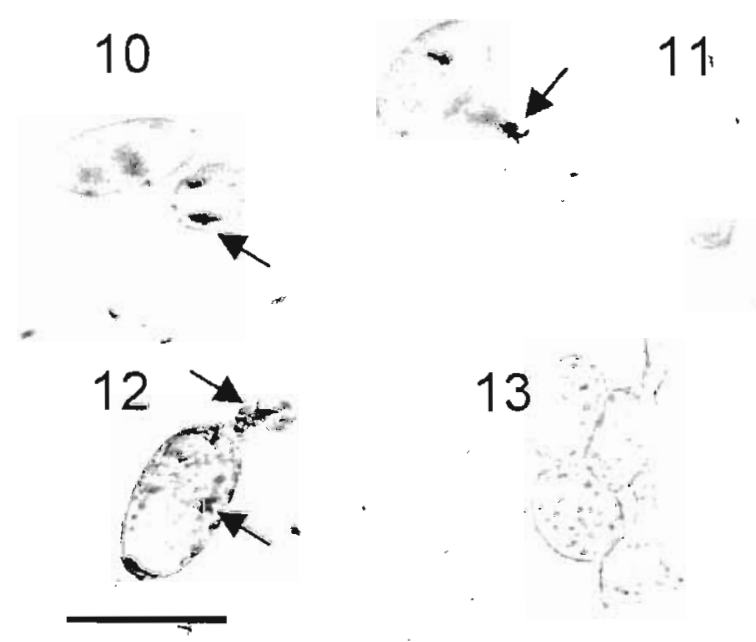

19) surfaces with morphogenesis on artificial substrata (Figs. 20 and 21) were made to clarify whether the extracellular material underneath spores and infection structures was of fungal origin or derived solely from partial dissolution of the plant cuticle.

At the edge of a freeze-fractured leaf disk of $V$. vinifera, a developing appressorium was broken, allowing an unhindered view of the host-fungus interface (Figs. 16 and 17). The infection structure appeared to be embedded in an extracellular matrix that was hardly distinguishable from the underlying cuticle (Fig. 17).

On the surface of $H$. vulgare cuticles that had been freed of epicuticular waxes. deposits or dissolutions were visible comparable with those observed on host tissue (Fig. 18). As found on grapevine leaves (Fig. 8), conidia often broke away from the primary appressorium, indicating that the adhesion of the appressorium was stronger than that of the spore (Fig. 19). In addition, extracellular material was found around appressoria on glass slides (Fig. 20). On a hydrophobic PVDF membrane, disorganized infection structures often formed (not shown). The germlings appeared to secrete material that covered membrane pores (Fig. 21).

LTSEM studies also indicated that pretreatment of grapevine cuticles with the cutinase inhibitor BIC had no effect on the formation of extracellular material at the host-fungus interface (Figs. 16 and 17). Furthermore, no significant differences in the adhesion of $U$. necator were found between BIC-treated samples and controls in adhesion assays (Fig. 22). 
Table 1. Inhibition of esterase and cutinase activity from spore washing solutions of $U$. necator.

\begin{tabular}{|c|c|c|c|c|}
\hline & \multicolumn{2}{|l|}{ Esterase activity } & \multicolumn{2}{|l|}{ Cutinase activity } \\
\hline & $\begin{array}{l}\text { Specific activity } \\
\left(\text { nkat } \cdot m g \text { protein }{ }^{-1}\right)^{a}\end{array}$ & $\begin{array}{l}\text { Inhibition } \\
(\%)\end{array}$ & $\begin{array}{l}\text { Specific activity } \\
\left(\text { Bq } \cdot \text { mg protein }{ }^{-1} \cdot h^{-1}\right)\end{array}$ & $\begin{array}{l}\text { Inhibition } \\
(\%)\end{array}$ \\
\hline Control & $208 \pm 117$ & - & $93 \pm 40$ & - \\
\hline \multicolumn{5}{|l|}{ DIPF } \\
\hline $10 \mu \mathrm{M}$ & $203 \pm 2$ & 2 & $43 \pm 32$ & 54 \\
\hline $100 \mu \mathrm{M}$ & $99 \pm 4$ & 52 & & \\
\hline \multicolumn{5}{|l|}{$\mathrm{BIC}$} \\
\hline $10 \mu \mathrm{M}$ & $173 \pm 36$ & 17 & & \\
\hline $100 \mu \mathrm{M}$ & $48 \pm 6$ & 77 & & \\
\hline
\end{tabular}

Note: Values are means $\pm S D$ of two independenl experiments with two repetitions each.

"1 $\mu \mathrm{mol} / \mathrm{min}=16.67 \mathrm{nkal}$.

Fig. 14. Extracellular spore proteins from spore washing solutions of $U$. necator separated by nondenaturing PAGE. Gel was incubated in $50 \mathrm{mM}$ Tris buffer ( $\mathrm{pH} 7.2)$ containing indoxyl acetate: lanes 1-3: washing solution from inoculated leaves (lane 1), uninoculated leaves (lane 2), and inoculated glass slides (lane 3); ]ane 4. esterase standard. The arrow indicates the protein band with esterase activity.

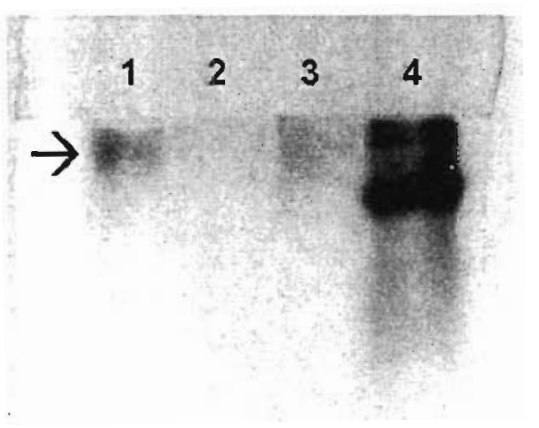

\section{Discussion}

Electron microscopy has repeatediy documented close contact between the infection structures of plant pathogenic fungi and their host plants (Howard et al. 1991; Braun and Howard 1994a). Such adhesion is thought to be required for disease initiation in plants (Mendgen 1996; Nicholson 1996: Epstein and Nicholson 1997). Hydrophobic interactions between spore surface and plant cuticle may contribute to early adhesion. as suggested by the LTSEM studies of Beckett and co-workers (Beckett et al. 1990; Clement et al. 1994). Initial adhesion could also depend on the presence of extracellular material deposited on the spore surface to ensure attachment of the spore to the plant surface, as has been postulated for powdery mildew fungi (Mims et al. 1995; Nicholson and Kunoh 1995). For $U$. necator the latter might also be relevant in the case of conidial and germling adhesion. The distinct temporal correlation between the formation of primary appressoria by $U$. necator and the dramatic increase in adhesion clearly indicates that fungal attachment is mediated mainly through the development of infection structures. The result is an enlarged contact zone between the pathogen and
Fig. 15. Southern blot of genomic DNA of $U$. necator. F. solani f.sp. pisi and $M$. grisea. A DIG-jabeled fragment (500 bp) of a cutinase gene from $F$. solani f.sp. pisi isolate $\mathrm{T} 8$ was used as a probe in hybridization $\left(68^{\circ} \mathrm{C}, 18 \mathrm{~h}\right)$. Autoradiogram of the blotting membrane: lanes 1-10, 30-min exposure time: lane 1 ,

NHindIII marker $(6.5,9.4$, and $23.1 \mathrm{~kb})$; lanes 2-4, U. necator: lanes 5-7. F. solani f.sp. pisi; lanes 8-10, M. grisea; lanes 2. 5. and 8: restriction digests with EcoRI: lanes 3, 6, and 9: restriction digests with HindIIl: lanes 4, 7. and 10: restriction digests with $\mathrm{BamHI}$; lane 11,15 -min exposure time, kilobase ladder).

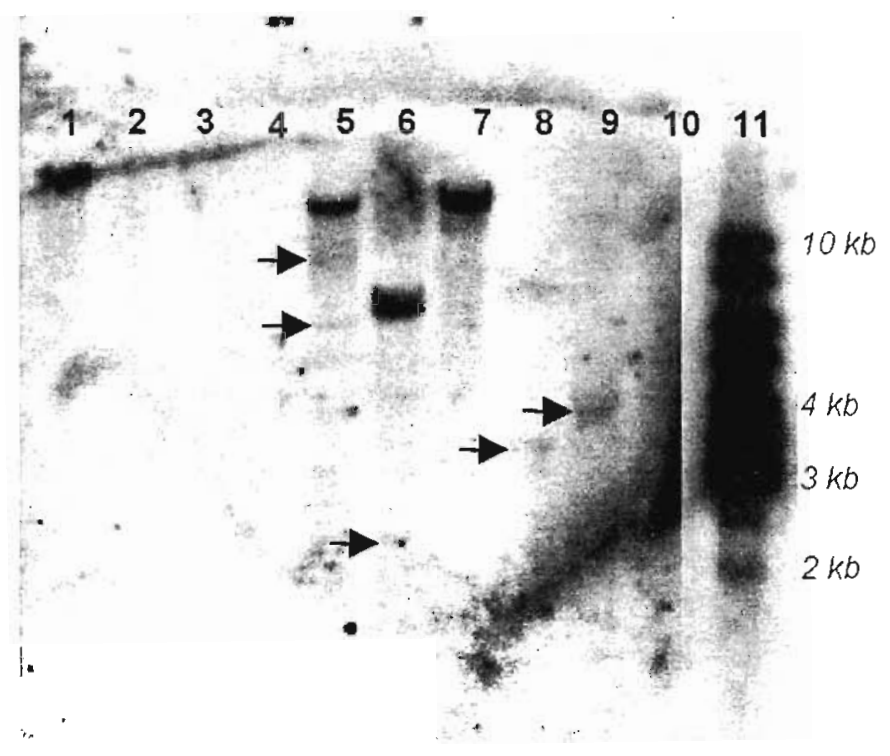

the hosi surface. Because the formation of infection structures is accompanied by deposits of extracellular material. it is conceivable that the degree of adhesion depends on the developmental stage of the fungus. Accordingly: for germlings of Botrytis cinerea (Doss et al. 1995) and Cochliobolus heterostrophus (Braun and Howard 1994b), the occurrence of extracellular material at the contact zone between plant and pathogen correlates with an increase in adhesion. Comparison of the kinetics of adhesion and infection-structure development in $U$. necator indicates that structures which differentiat after primary appressoria have developed, that is, primary and secondary hyphae. do not significantly contribute to adhesion to the host cuticle. This is in line with earlier findings for $E$. graminis on wheat (Merchán and Kranz 1986). 
Figs. 16-21. LTSE micrographs of primary appressoria of $U$. necator on host and non-host surface or on artificial substrata. Fig. 16. Freeze-fractured leaf disk of $V$. vinifera pretreated with the cutinase inhibitor BIC $(100 \mu \mathrm{M})$. Conidium $(\mathrm{C})$ and germ tube appressorium (Gt) of $U$. necator are firmly adhered to the surface of an epidermal cell (E). Fig. 17. Detail of Fig. 16. The germ tube (G) appears to be embedded in an extracellular matrix (ECM) and (or) in cuticle (Cu) layers. Note material (D) underneath the germ tube inside the epidermal cell. Fig. 18. Appressorium (PA) on the cuticle ( $\mathrm{Cu}$ ) of H. vulgare. Deposits of extracellular material are visible (arrows). Epicuticular waxes were stripped off before inoculation. Fig. 19. Fracturing of the neck of the appressorium (PA) proves that the infection structure adhered firmly to the cuticle $(\mathrm{Cu})$ of $H$. inlgare. Extracellular or cell wall material remains on the plant surface at the former position of a conidium (arrow). Fig. 20. Appressorium (PA) on a glass slide. Note the deposition of extracellular material (arrow). Fig. 21. Appressorium (PA) on PVDF membrane (M). Membrane pores underneath the appressorium are covered by a film (arrow).
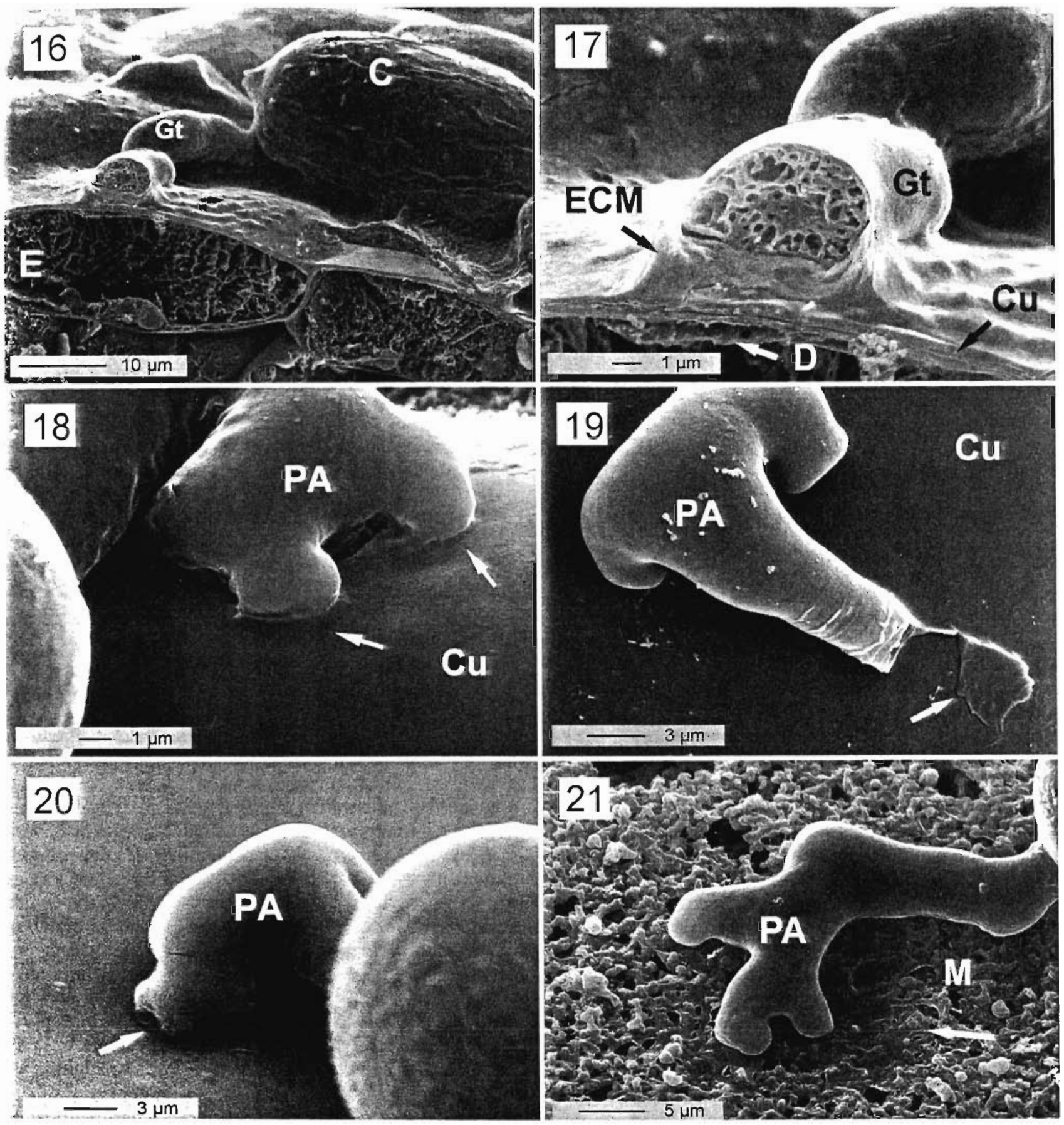

Extracellular matrix material was found at the contact site between conidia and infection structures (including primary appressoria) of $U$. necator and the cuticle of host and non-

host tissue. Extracellular material was also observed underneath fungal structures of already established colonies of U. necator (Heintz and Blaich 1990; Leinhos et al. 1997) 
Fig. 22. Adhesion of conidia of $U$. necalor on leaf disks of $V$ vinifera $c v$. Müller-Thurgau pretreated with the cutinase inhibitor BIC. Inoculated leaf disks were incubated at $17^{\circ} \mathrm{C}$. Values are means of six independent experiments. Each experiment included four leaf disks of each variant. Error bars represent standard deviation.

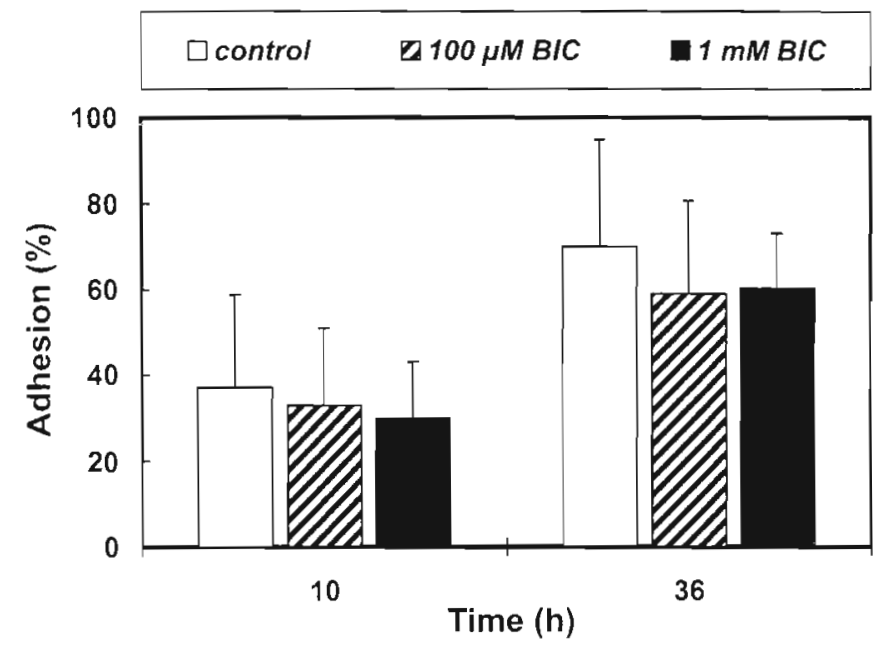

and underneath infection structures of the powdery mildew of cereals, E. graminis (Carver et al. 1995a). The cryofixation technique enabled the study of preparations with appressoria tightly attached to the host surface. Partial detachment of early infection structures was only achieved by fracturing the specimens. The observed shreds of adhesive material and the embedded appressorial germ tube suggest that the deposition of extracellular material and (or) localized enzymatic action occur to glue appressorium and spore to the host surface. The fact that germinated conidia broke away from appressoria leaving behind adhesion pads of spores and firmly attached appressoria support this assumption. The possibility that penetration hyphae that have already emerged contribute to the adhesion of appressoria by anchoring the fungus to the host epidermis is negligible, as no penetration pores were found after the removal of fungal structures with gelatin. As documented by Figs. 1-3, adhesion starts much earlier than colonization of the host tissue. In contrast with findings by Leinhos et al. (1997). our study indicates that the the extracellular material is present at a pre-penetration stage, in which fungal metabolism is still restricted to the limited nutrients within the spore.

As reported for E. graminis (Kunoh et al. 1988; Carver et al. 1995a, 1999), extracellular material beneath the conidia on leaf surfaces could not be shown consistently. The reticulate spore surface we observed on some turgid conidia (Fig. 5) might be an additional layer resembling an exudate, as described for other powdery mildews (see Kunoh et al. 1988: Mims et al. 1995). Because adhesion occurred coincidently with germination, we did not focus on conidium surface morphology from contact with the substratum unti] germination. However, some preliminary experiments reveaied conidia with a reticulate surface 15 min p.i. on the surface of grapevine leaves (data not shown).

The extracellular material secreted by the infection structures of many plant pathogenic fungi commonly consists of adhesives, that is, polysaccharides, proteins, and glycopro- teins, and enzymes like esterases and cutinase (Nicholson 1996). In spite of the enormous experimental effort expended on experiments involving chemical and antibody inhibition, gene complementation of wound pathogens, and gene inactivation in several fungi (Maiti and Kolattukudy 1979; Dickman et al. 1982, 1989; Stahl and Schäfer 1992: Sweigard et al. 1992), the role of cutinase in pathogenesis is still controversial (Stahl and Schäfer 1992; Rogers et al. 1994; Schäfer 1994; Stahl et al. 1994). Yao and Köller (1995) demonstrated the expression of a cutinase gene specifically during pathogenic development. Since the pathogenesisspecific cutinase gene seems to significantly differ in its DNA sequence from those expressed under saprophytic growth conditions, gene inactivation experiments that rely on homologous recombination may not have affected the infection-related genes (Köller et al. 1995).

Because cutinases are a component of fungal extracellular matrices in contact with the host surface (Pascholati et al. 1992; Carver et al. 1995b), it is conceivable that these enzymes, together with the extracellular matrices, directly affect adhesion. Deising et al. (1992) have shown that a cutinase and two nonspecific serine esterases are associated with urediospores of the broad bean rust fungus Uromyces viciae-fabae. Chemical inhibition of the enzymes resulted in reduced spore adhesion. Accordingly, the addition of spore washing fluids containing the active cutinase and esterases, or individual addition of these enzymes, to autoclaved spores complemented adhesion. It is important to emphasize that the enzymes of rust fungi appear to be a component of the extracellular matrix surrounding the urediospore. The work by Deising et al. (1992) suggested that cutinase and nonspecific esterases play a role in adhesion, in addition to the known role played in cutin dissolution during penetration reported for several necrotrophs (Dickman et al. 1989: Kolattukudy et al. 1995).

Esterase activity was localized on the spore surface and on developing infection structures of $U$. necator. Similar reports already exist for the powdery mildew fungus E. graminis (Nicholson et al. 1988), the fruit pathogen Colletotrichum gloeosporioides (Podila et al. 1995), and the rust fungus $U$. viciae-fabae (Deising et al. 1992). Cutinase may support the adhesion of spores and infection structures, possibly by locally altering the surface. However, it is still speculative whether covalent bonds are formed between fungus and host on a cutinase-treated cuticle (Epstein and Nicholson 1997). Because the cutinase inhibitor did not completely eliminate enzyme activity (Table 1). and because the remaining activity could well be sufficient to establish the conidium on the plant surface. no clear conclusion can be drawn from the inhibitor experiments. Although the involvement of $\mathrm{cu}-$ tinase genes has been studied by gene disruption assays in other fungal plant pathogens, this approach is difficult to take with obligate biotrophs, and will only become possible after stable rather than transient transformation systems (Bhairi and Staples 1992; Li et al. 1993; Christiansen et al. 1995) become available.

The question as to whether extracellular matrices surrounding fungal infection structures are secreted by fungi or also consist of dissolved cutin and wax, is controversial (Hamacher 1987; Kunoh et al. 1990; Carver et al. 1995a. 1995b). The occurrence of extracellular material underneath 
appressoria of $U$. necator on artificial substrata such as glass and PVDF suggests a mechanism independent of enzymatic action and shows the fungal origin of the matrix. However detection by monoclonal antibodies of cutinase in close association with infection structures of the powdery mildew E. graminis growing on cellulose dialysis membranes (S.A. Francis. F.M. Dewey. S.J. Gurr, and T.L.W. Carver. unpublished data) suggests that the enzyme is a constitutive component of the matrix. The fact that BIC pretreatment of I'. vinifera leaf disks did not hinder deposition of extracellular material (Fig, 16 and 17) or adhesion of conidia (Fig. 22) is not contradictory to the latter, because other substances like carbohydrates, lipids, and (glyco-) proteins, insluding cell wall degrading enzymes have been reported to be main components of fungal extracellular matrices (Sugui et al. 1998: Suzuki et al. 1998; Doss 1999). Interestingly, protein present in remnants of extracellular matrices from displaced conidia and germ tubes of $B$. graminis seem to accumulate mainly around germ tubes (Carver et al. 1999), which represent structures identical to the germ tubes and primary appressoria of $U$. necator.

The results of high stringency Southern blot analyses indisate that the cutinase gene of $U$. necator shares only limited, if any sequence similarity with the cutinase genes of the necrotrophs $F$. solani f.sp. pisi and $M$. grisea. However, the function of the gene product and its role in pathogenesis are still unknown. Owing to a lack of appropriate mutants. the involvement of cutinase in fungal adhesion could not be conclusively proven in the case of the biotrophs $U$. viciae-fabae and E. graminis. However, the formal proposal that cutinases contribute to the attachment of fungi to host surfaces, first made by Deising et al. (1992) and Nicholson (1996), is still valid. As a component of the extracellular matter exuded by conidia and infection structures, cutinase remains a candidate in aiding $U$. necator to adhere firmly to its host.

\section{Acknowledgements}

Thanks to M. Düggelin for skillful technical support and :o $\mathrm{H}$. Christen for valuable discussions on data analysis. The authors are further obliged to $\mathrm{C}$. and $\mathrm{M}$. Couderchet for reading the manuscript and translating the abstract. This study was supported by Ministerium für Ländlichen Raum Baden-Württemberg. Germany.

\section{References}

Barnett. R.J., and Seligman. A.M. 1951. Histochemical demonstration of esterases by production of indigo. Science (Washington. D.C.). $114: 579-582$

Beckett. A.. Tatnell. J.A.. and Taylor. N. 1990. Adhesion and preinvasion beharior of urediniospores of Uromyces viciae-fabae during germination on host and synthetic surfaces. Mycol. Res. 94: $865-875$

Bhari. S.M... and Staples. R.C. 1992. Transient expression of the B-glucuronidase gene introduced into Uromyces appendiculauis uredospores by particle bombardment. Phytopathology. 82: 986-989.

Bonnen. A.M.. and Hammerschmidt. R. 1989. Cutinolytic enzymes irom Collerotricium lagenarium. Physiol. Mol. Plant Pathol. 35 . $+6,3+74$
Bradford, M.M. 1976. A rapid and sensitive method for the quantification of microgram quantities of protein utilizing the principle of prolein-dye binding. Anal. Biochem. 72: 248-254.

Braun, E.J.. and Howard. R.J. 1994a. Adhesion of fungal spores and germlings to host plant surfaces. Protoplasma. 181: 202-212.

Braun, E.J., and Howard, R.J. 1994b. Adhesion of Cochliobolus heterostrophus conidia and germlings to leaves and artificial surfaces. Exp. Mycol. 18: 211-220.

Bulit, J.. and Lafon. R. 1978. Powdery mildew of the vine. In The powdery mildews. Edited by: D.M. Spencer. Academic Press. London. pp. 525-548.

Carver, T.L.W., and Thomas, B.J. 1990. Normal germling development by Erysiphe graminis on cereal leaves freed of epicuticular wax. Planı Pathol. 39: 367-375.

Carver, T.L.W. Thomas, B.J., and Ingerson-Morris, S.M.' 1995 a. The surface of Ensiphe graminis and the production of extracellular material at the fungus-host interface during germling and colony development. Can. J. Bot. 73: 272-287.

Carver, T.L.W., Ingerson-Morris, S.M., Thomas. B.J.. and Zeyen, R.J. 1995b. Early interactions during powdery mildew infection. Can. J. Bot. 73(Suppl.): 632-639.

Carver, T.L.W. Kunoh, H.. Thomas. B.J., and Nicholson, R.L. 1999. Release and visualization of the extracellular matrix of conidia of Blumeria graminis. Mycol. Res. 103: 547-560.

Chellemi. D.O.. and Marois, J.J. 1991. Effect of fungicides and water on sporulation of Uncinula necator. Plant Dis. 75: 455-457.

Christiansen, S.K.. Knudsen. S., and Giese, H. 1995. Biolistic transformation of the obligate plant pathogenic fungus, Erysiphe graminis f.sp hordei. Curr. Genet. 29: 100-102.

Clement. J.A.. Porter. R., Butt, T.M., and Beckett. A. 1994. The role of hydrophobicity in attachment of urediniospores and sporelings of Uromyces viciae-fabae. Mycol. Res. 98: 1217-1228.

Dean, R.A. 1997. Signal pathways and appressorium morphogenesis. Annu. Rev. Phytopathol. 35: 211-234.

Deising, H., Nicholson. R.L., Haug, M., Howard, R.J., and Mendgen K. 1992. Adhesion pad formation and the involvement of cutinase and esterases in the attachment of uredospores to the host cuticle. Plant Cell. 4: 1101-1111.

Delp. C.J. 1954. Sporulation of Uncinula necator on grape leaves as influenced by temperature and cultivar. Phytopathology, 44 615-626.

Dickman. M.B.. Patil. S.S.. and Kolattukudy. P.E. 1982. Purification, characterization and role in infection of an extracellular cutinolytic enzyme from Colletotrichum gloeosporioides Penz. on Carica papaya L. Physiol. Plant Pathol. 20: 333-347.

Dickman. M.B. Podila, G.K.. and Kolattukudy. P.E. 1989. Insertion of a cutinase gene into a wound pathogen enables it to infect intaci host. Nature (London). 342: 446-448.

Doss. R.P. 1999. Composition and enzymatic activity of the extracellular matrix secreted by germlings of Botrinis cinerea. Appi. Environ. Microbiol. 65: 404-408.

Doss. R.P.. Potter. S.W.. Soeldner. A.H.. Christian. J.K.. and Fukunaga. L.E. 1995. Adhesion of germlings of Botryis cinerea Appl. Environ. Microbiol. 61: 260-265.

Epstein. L.. and Nicholson. R.L. 1997. Adhesion of spores and hyphae to plant surfaces. In The Mycota. Vol. V. Part A. Edited b. G. Carroll and P. Tudzynski. Springer. Beriin. New York. pp. $11-25$

Francis. S.A.. Dewey. F.M.. and Gurr. S.J. 1996. The role of cutinase in germling development and infection by Ervsiphe graminis f.sp. hordei. Physiol. Mol. Plant Pathol. 49: 201-211.

Frič. F.. and Wolf, G. 1994. Hydrolytic enzymes of ungerminated and germinated conidia of Erysiphe graminis DC f.sp. hordei Marchal. J. Phytopathol. (Berl.), 140: 1-10. 
Guggenheim, R.. Düggelin, M.. Mathys, D., and Grabski, C. 1991. Low-temperature SEM for the detection of fungicide activity. J. Microsc. 161: 337-342.

Hamacher. J. 1987. Der Haustorienkomplex von Erysiphe betae (Vanha) Weltzien. J. Phytopathol. (Berl.), 118: 289-300.

Heintz. C. 1986. Infection mechanisms of grapevine powdery mildew (Oidium tuckeri): comparative studies of the penetration process on artificial membranes and leaf epidermis. Vitis, 25: $215-225$.

Heintz. C.. and Blaich. R. 1990. Ultrastructural and histochemical studies on interactions between Vitis vinifera $\mathrm{L}_{\text {., }}$ and Uncinula necalor (Schw.) Burr. New Phytol. 115: 107-117.

Howard, R.J., Ferrari, M.A., Roach, D.H., and Money, N.P. 1991. Penetration of hard substrates by a fungus employing enormous turgor pressures. Proc. Natl. Acad. Sci. U.S.A. 88: 11281 11284 .

Huggins, C., and Lapides, J. 1947. Chromogenic substrates. IV. Acyl esters of $p$-nitrophenol as substrates for the colorimetric determination of esterase. J. Biol. Chem. 170: 467-482.

Kolattukudy, P.E.. Purdy, R.E., and Maiti, I.B. 1981. Cutinases from fungi and pollen. Methods Enzymol. 71: 652-660.

Kolattukudy, P.E.. Rogers, L.M.. Li, D., Hwang, C.S., and Flaishman, M.A. 1995. Surface signaling in pathogenesis. Proc. Natl. Acad. Sci. U.S.A. 92: 4080-4087

Köller, W.. Allan. C.R., and Kolattukudy. P.E. 1982. Inhibition of cutinase and prevention of fungal penetration into plants by benomyl-a possible protective mode of action. Pestic. Biochem. Physiol. 18: 15-25.

Köller, W., Yao. C., Trail, F., and Parker. D.M. 1995. Role of cutinase in the invasion of plants. Can. J. Bot. 73(Suppl.): 1109-1118.

Kunoh, H. Yamaoka. N.. Yoshioka. H., and Nicholson, R.L. 1988. Preparation of the infection court by Erysiphe graminis: I. Contact-mediated changes in morphology of the conidium surface. Exp. Mycol. 12: 325-335.

Kunoh. H.. Nicholson, R.L., Yoshioka, H., Yamaoka, N., and Kobayashi. I. 1990. Preparation of the infection court by Erysiphe graminis: degradation of the host cuticle. Physiol. Plant Pathol. 36: $397-407$.

Laemmli. U.K. 1970. Cleavage of structural proteins during the assembly of the head of bacteriophage T4. Nature (London). 227: 680-685.

Lee. Y.-H.. and Dean, R.A. 1993. cAMP regulates infection structure formation in the plant pathogenic fungus Magnaporthe grisea. Plant Cell. 5: 693-700.

Leinhos. G.M.E.. Gold. R.E.. Düggelin. M.. and Guggenheim. R. 1997. Development and morphology of Uncinula necaror following treatment with the fungicides kresoxim-methyl and penconazole. Mycol. Res. 101: 1033-1046.

Li. A.. Altosaar. 1.. Heath. M.C., and Horgen. P.A. 1993. Transient expression of the beta-glucuronidase gene delivered into urediniospores of Lromyces appendiculatus by particle bombardment. Can. J. Plant Pathol. 15: 1-6.

Maiti. I.B.. and Kolattukudy. P.E. 1979. Prevention of fungal infection of plants by specific inhibitor of cutinase. Science (Washington. D.C.). 205: 507-508.

Mendgen. K. 1996. Fungal attachment and penetration. In Plant cuiicles. Ediued by G. Kerstiens. BIOS Scientific Publishers. Oxford. pp. 175-187.

Mendgen. K.. and Deising. H. 1993. Infection structures of plant pathogens-a cytological and physiological evaluation. New Phviol 124: 193-213.
Mendgen, K.. Hahn, M., and Deising. H. 1996. Morphogenesis and mechanisms of penetration by plant pathogenic fungi. Annu. Rev. Phytopathol. 34: 367-386.

Merchán, V.M., and Kranz, J. 1986. Untersuchungen über den Einfluß des Regens auf die Infektion des Weizens durch Erysiphe graminis DC f.sp. tritici Marchal. Z. Pflanzenkr. Pflanzenschutz, 93: 255-261

Mims, C.W., Liljebjelke, K.A., and Richardson. E.A. 1995. Surface morphology, wall structure, and initial adhesion of conidia of the powdery mildew fungus Uncinuliella australiana. Phytopathology, 85: 352-358.

Möller, E.M., Bahnweg, G., Sandermann, H., and Geiger. H.H. 1992. A simple and efficient protocol of high molecular weight DNA from filamentous fungi, fruit bodies, and infected plant tissues. Nucleic Acids Res. 20: 6615-6616.

Müller, T., Guggenheim, R., Düggelin, M., and' Scheidegger. C. 1991. Freeze fracturing for conventional and field emission lowtemperature scanning electron microscopy: the cryo scanning unit SCU 020. J. Microsc. 161: 73-83.

Nicholson, R.L. 1996. Adhesion of fungal propagules: significance to the success of the fungal infection process. In Histology, ultrastructure and molecular cytology of plant-microorganism interactions. Edited by M. Nicole and V. Gianinazzi. Kluwer Academic Publishers. Dordrecht. pp. 117-134.

Nicholson. R.L., and Kunoh, H. 1995. Early interactions, adhesion, and establishment of the infection court by Erysiphe graminis. Can. J. Bot. 73(Suppl.): 609-615.

Nicholson, R.L., Yoshioka, H., Yamaoka. N., and Kunoh, H. 1988. Preparation of the infection court by Erysiphe graminis: II. Release of esterase enzyme from conidia in response to a contact stimulus. Exp. Mycol. 12: 336-349

Nicholson. R.L.. Kunoh, H., Shiraishi. T., and Yamada, T. 1993. Initiation of the infection process by Erysiphe graminis: conversion of the conidial surface from hydrophobicity to hydrophilicity and influence of the conidial exudate on the hydrophobicity of the barley leaf surface. Physiol. Mol. Plant Pathol. 43: 307-318.

Pascholati, S.F., Yoshioka, H.. Kunoh. H., and Nicholson. R.L. 1992. Preparation of the infection court by Erysiphe graminis f.sp. hordei: cutinase is a component of the conidial exudate. Phvsiol. Mol. Plant Pathol. 41: 53-59.

Pearson, R.C., and Goheen, A.C. 1988. Compendium of grape diseases. American Mycological Society. APS Press, St. Paul.

Podila. G.K.. Rosen, E., San Fransisco. M.J.D., and Kolattukudy, P.M. 1995. Targeted secretion of cutinase in Fusarium solani f.sp. pisi and Colletorichum gloeosporioides. Phytopathology, 85: 238-242.

Roberts. D.R. and Mims. C.W. 1998. Ultrastructure of extracellular matrix deposits associated with conidia of the powdery mildew fungus Blumeria graminis f.sp. hordei. Int. J. Plant. Sci. 159: $575-580$

Rogers. L.M.. Flaishman. M.A... and Kolattukudy. P.E. 1994. Cutinase gene disruption in Fusarium solani f.sp. pisi decreases its virulence on pea. Plant Cell, 6: 935-945

Sambrook. J.. Fritsch. E.F.. and Maniatis. T. 1989. Molecular cloning: a laboratory manual. 2nd ed. Cold Spring Harbour Laboratory Press, Cold Spring Harbor. New York.

Schäfer. W. 1994. Molecular mechanisms of fungal pathogenicity to plants. Annu. Rev. Phytopathol. 32: 461-477.

Shaykh, M., Soliday. C.L., and Kolattukudy, P.E. 1977. Proof for the production of cutinase by Fusarium solani f.sp. pisi during penetration into its host, Pisum saivum. Plant Physiol. 60: 170-172.

Sivapalan, A. 1993. Effects of impacting rain drops on the growth and development of powdery mildew fungi. Plant Pathol. 42 
$256-263$.

Stahl. D.J.. and Schäfer. W. 1992. Cutinase is not required for fungal pathogenicity on pea. Plant Cell. 4: 62l-629.

Stahl. D.J.. Theuerkauf. A., Heitefuss, R., and Schäfer. W. 1994. Cutinase of Nectria haemalococca (Fusarium solani f.sp. pisi) is not required for virulence or organ specificity. Mol. PlantWicrobe Interact. 7: 713-725.

Staub. I.. Dahmen. H.. and Schwinn, F.J. 1974. Light and scanning electron microscopy of cucumber and barley powdery mildew an host and non host plants. Phytopathology. 64: 364-372.

Sugui. J.A.. Leite. B.. and Nicholson. R.L. 1998. Partial characterization of the extracellular matrix released onto hydrophobic curtices by conidia and conidial germlings of Colletorrichum graminicola. Physiol. Mol. Plant Pathol. 52: $411-425$.

Suzuki. S.. Komiya. Y., Mitsui. T.. Tsuyumu. S.. Kunoh. H.. Carver. T.L.W., and Nicholson. R.L. 1998. Release of cell wall degrading enzymes from conidia of Blumeria graminis on artificial substrata. Ann. Phytopathol. Soc. Jpn. 64: 160-167.

Sweigard. J.A.. Chumley, F.G.. and Valent. B. 1992. Disruption of a Magnaporthe grisea cutinase gene. Mol. Gen. Genet. 232: $183-190$.

Yao. C.. and Köller. W. 1995. Diversity of cutinases from plant pathogenic fungi: different cutinases are expressed during saprophytic and pathogenic stages of Altemaria brassicicola. Mol. Plant-Microbe Interact. 8: 122-130 